\title{
The Effects of Business Magazine Recommendations on the Stock Prices in Turkey: Case of Para*
}

\author{
Türkiye'de Ekonomi Dergillerinde Yer Alan Tavsiyelerin Hisse \\ Fiyatları Üzerindeki Etkisi: Para Örneği
}

\section{Dr. Kemal Eyüboğlu - Assoc. Prof. Dr. Halil Ibrahim Bulut}

\begin{abstract}
The paper examines the effects of business magazines recommendations on the stock returns. For this purpose, it is analyzed whether investors can gain abnormal returns from the "buy" recommendations given by the weekly magazine "Para" cover the period February 2006-December 2012. The findings show that recommendations cannot help investors to earn abnormal returns from stocks. The reason of this might be the low circulation of business magazines in Turkey. In addition, it is determined that recommended stock performances are only $1.2 \%$ higher than the BIST-100 index performance in the long term.
\end{abstract}

Keywords: Abnormal return, stock recommendation, BIST, business magazine, event study

\section{Öz}

Bu çalışmanin amacı ekonomi dergilerinde yer alan tavsiyelerin hisse senetleri üzerindeki etkisini araştırmaktır. Bu amaçla Şubat 2006-Aralik 2012 dönemi için Para Dergisinde yer alan "al" tavsiyelerinin yattrımcıların aşırı getiriler elde etmesine yardımo olup olmadĭ̆ incelenmiştir. Elde edilen bulgular dergide yer alan tavsiyelerin yatırımcıların herhangi bir aşırı getiri elde etmesine yardımo olmadığın göstermiştir. Bu durumun dergi tirajlarının Türkiye'de çok düşük seviyelerde olmasından kaynaklandiğı düşünülmektedir.
İlaveten uzun dönemde tavsiye edilen hisse senetleri performansinin BIST-100 endeks performansina göre $\% 1,2$ daha iyi olduğu tespit edilmiştir.

Anahtar Kelimeler: Aşırı Getiri, Hisse Tavsiyesi, Bist, Ekonomi Dergiciliği, Olay Çalışması

\section{Introduction}

The stock markets take an important place in financial markets and news in these markets has become one of the most fundamental equity instruments. Especially individual investors are interested and they closely follow developments in the market. The market can be watched by many sources; in particular by the financial media.

The development of the capital markets began in 1990s and the interest of media to these markets took place in parallel. Financial media focused its attention on stocks, warrants, and mutual funds by the time of progress and it also concentrated on the way of process to gain through the use of those instruments (Schuster, 2003, p. 4). Especially business magazines has an effect today's high-tech and fast serving information intermediaries such as websites and data feeds. Also business magazines continue to provide useful information or recommendation about stocks to readers who are interested in financial markets

Dr. Kemal Eyüboğlu, Karadeniz Teknik University, keyuboglu@ ktu.edu.tr

Assoc. Prof. Dr. Halil İbrahim Bulut, Karadeniz Teknik University, halibo@ktu.edu.tr

* This study was declared in $17^{\text {th }}$ Finance Symposium as a report. 
and in the process of making investment decision (Palmon et.al, 2009, p. 210). There have been many published magazines for the same purpose in Turkey. It is worth to investigate whether these recommendations can help readers to earn abnormal returns. One of the most examined topics in the last 40 years in the field of finance is the Efficient Market Hypothesis (EMH). The term of efficient market was first presented by Fama (1970) and it was defined as "market quickly adaption to new information". This hypothesis is based on the assumption that investors behave rationally, different kinds of information related to stocks could be obtained by investors; thus the price of stocks is determined in the term of this information. In the semi strong efficient form, since new information is disclosed to the public, investors will also assess it. Thus, the news would be reflected immediately to price so any investor cannot gain abnormal returns. However it has been reached some findings conflict with EMH in the literature. Many studies investigating corporate events, dividend news, stocks splits and stock recommendations indicate that the news has been gradually disseminated among investors and this can be effect the stock prices (Yoon and Starks, 1995; Wuff, 2002; Brooks et al., 2003; Graham et al., 2006; Kalay and Kronlund, 2014). The current study examines the effects of business magazine recommendations on the stock prices. For this purpose, it is analyzed whether investors can gain abnormal returns from the buy recommendations given by the weekly magazine Para cover the period February 2006- December 2012. Also Borsa Istanbul (BIST) is tested within semi strong efficient form. This paper is organized as follows. Section 2 explains history of the BIST and business magazines in Turkey. Section 3 provides an overview of the literature. Section 4 describes the data and explains the methodology and presents the empirical results and Section 5 includes conclusion.

\section{Borsa Istanbul and Business Magazines in Turkey}

\section{History of BIST}

In Turkey, capital markets were organized by the Capital Markets Act in 1981. After that on October 6, 1984 "Securities Regulation on the Establishment and Operation Principles of the Stock Exchange" was published. On December 26 in 1985 The Istanbul Stock Exchange (ISE) was established with an official opening ceremony and started operations on January 3 in 1986. The number of companies listed on the ISE was 80 and the market capitalization was 938 million dollars as of the end of foundation year. It has been developed in years and has increased the number of companies and market capitalization. As shown in Figure 1, the market capitalization reached 315 billion dollars and the number of traded companies reached 415 by the end of 2012 .

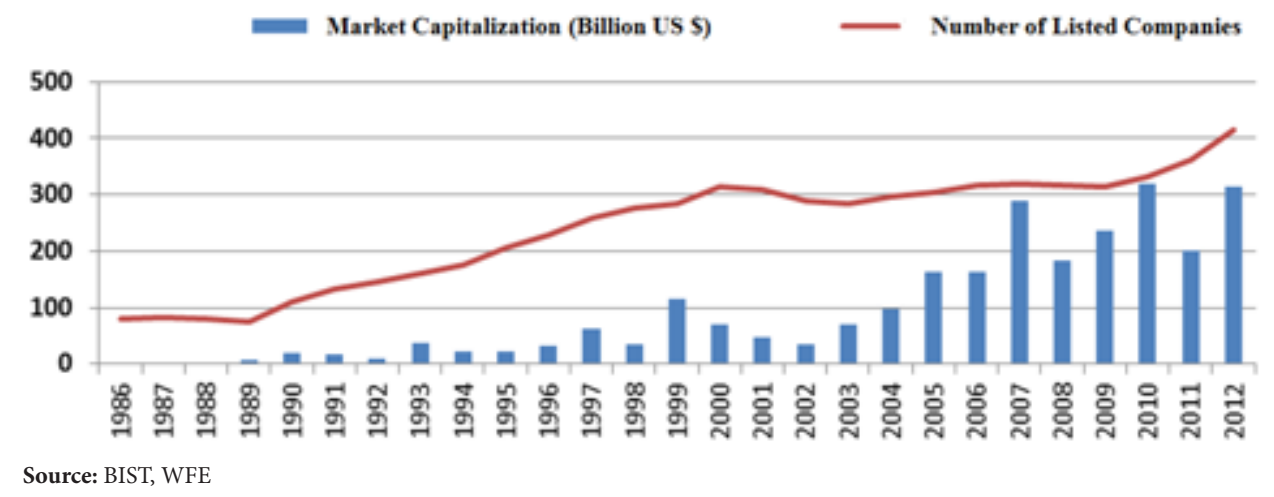

Figure 1. Market Capitalization and Number of Listed Companies by Years in BIST

ISE has changed its name to Borsa Istanbul (BIST) in 2013. All the exchanges operating in Turkish capital markets were gathered under the same roof by BIST.
The fundamental purpose and field of activity of BIST is described as follows: In accordance with the provisions of the Law and the related legislation, to 
ensure that capital markets instruments, foreign currencies, precious metals and gems, and other contracts, documents, and assets approved by the Capital Markets Board of Turkey are traded subject to free trade conditions in a facile and secure manner, in a transparent, efficient, competitive, fair and stable environment; to create, establish and develop markets, sub-markets, platforms, systems and other organized market places for the purpose of matching or facilitating the matching of the buy and sell orders for the above mentioned assets and to determine and announce the discovered prices; to manage and/or operate the aforementioned or other exchanges or markets of other exchanges; and to carry out the other activities listed in its Articles of Association (borsaistanbul. com). As shown in the Figure 2 market capitalization of BIST ranked as $28^{\text {th }}$ among all the members of World Federation of Exchanges (WFE) and also ranked in the $26^{\text {th }}$ among the number of listed companies in 2012 .

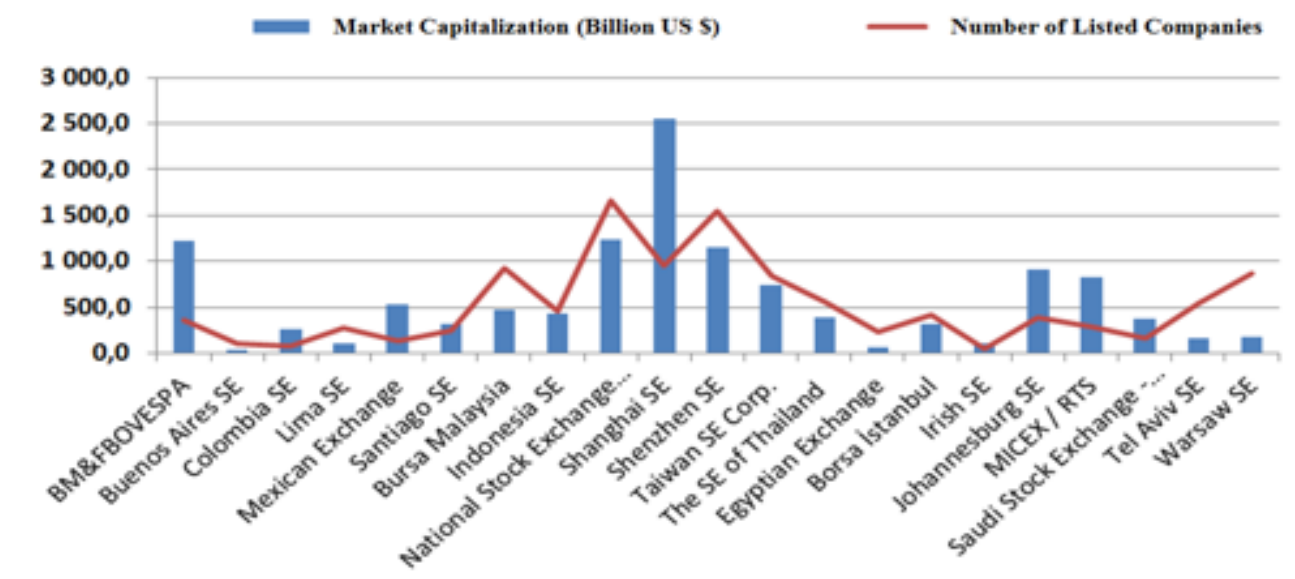

Source: BIST, WFE

Figure 2. Market Capitalizations and Number of Listed Companies of Emerging Countries Stock Exchanges in 2012

Table 1. Emerging Countries Stock Exchanges Performances in 2010-2011-2012

\begin{tabular}{|c|c|c|c|}
\hline \multirow{2}{*}{ Stock Exchange } & \multicolumn{3}{|c|}{ Performances (US Dollar Based) } \\
\cline { 2 - 4 } & $\mathbf{2 0 1 0}$ & $\mathbf{2 0 1 1}$ & $\mathbf{2 0 1 2}$ \\
\hline BM\&FBOVESPA & $15,6 \%$ & $-20,5 \%$ & $-0,1 \%$ \\
\hline Buenos Aires SE & $39,7 \%$ & $-31,8 \%$ & $-21,4 \%$ \\
\hline Colombia SE & $48,4 \%$ & $-3,5 \%$ & $30,2 \%$ \\
\hline Mexican Exchange & $29,1 \%$ & $-10,0 \%$ & $28,5 \%$ \\
\hline Santiago SE & $48,1 \%$ & $-20,9 \%$ & $15,9 \%$ \\
\hline Indonesia SE & $67,7 \%$ & $8,2 \%$ & $9,8 \%$ \\
\hline Philippine SE & $82,2 \%$ & $4,9 \%$ & $38,9 \%$ \\
\hline Shanghai SE & $0,4 \%$ & $-13,2 \%$ & $8,1 \%$ \\
\hline Shenzhen SE & $51,0 \%$ & $-19,6 \%$ & $9,1 \%$ \\
\hline The Stock Exchange of Thailand & $56,9 \%$ & $-3,3 \%$ & $45,2 \%$ \\
\hline Borsa Istanbul & $30,5 \%$ & $-34,8 \%$ & $59,9 \%$ \\
\hline Budapest SE & $-7,8 \%$ & $-32,2 \%$ & $10,6 \%$ \\
\hline Irish SE & $-1,5 \%$ & $79,6 \%$ & $0,5 \%$ \\
\hline Saudi Stock Exchange & $10,9 \%$ & $-4,1 \%$ & $10,2 \%$ \\
\hline Tel Aviv SE & $20,6 \%$ & $-31,1 \%$ & $3,1 \%$ \\
\hline Warsaw SE & $26,3 \%$ & $-27,5 \%$ & $28,3 \%$ \\
\hline Wiener Börse & $10,5 \%$ & $-32,3 \%$ & $24,4 \%$ \\
\hline
\end{tabular}

Source: WFE 
Moreover, as shown in the Table 1, BIST ranked the best performance among the emerging stock market registered into WFE in 2012.

\section{Business Magazines in Turkey ${ }^{1}$}

The first journal in the field of economics was started with the publishing of Dersaadet. After that, in 1969, economic news was seen on the pages of the newspaper, Milliyet.

In Turkey, several economic developments such as the establishment of financial markets, the release of exchange rate, the liberalization of the foreign trade, openness of the economy, and switching to free competition scheme had occurred in 1980s. All these developments have led to the need for information and news about the new economic era. Thus, in real terms economic journalism began in the 1980s. The economic news in daily newspapers was emerged as two pages at first, and then increased to ten. In this period Economic Panorama was published and it was followed by Para and Trend. Capital was published in 1992. Following these magazines Macro, Platinum, Globus, Power, Borsac1, Borsamatik and Seans were published respectively.
Another improvement seen in this period is that getting Turkey licenses of famous economics magazines of Western countries from media establishments and reaching them to the Turkish readers. Even if many newspapers and magazines have been closed due to low circulation just after they published, the financial press still has got progress in this period. Many publications either successful or unsuccessful have been launched one after another. As time passes, the number of economic pages has increased, qualified analysts have been trained. However, there has been an increase in the news which could be considered as a propagandism on behalf of big holdings and banks in the economy journals. On the other hand, there has been a new understanding of journalism that aim to benefit for the economics pages. Economics services have been perceived as a bridge between administration and business world to make or sustain connections; in return to advertisement stream for the newspaper. This expectation could be seen as a barrier against the development of business media.

Weekly publications are trying to survive with sensational cover topics. Business success stories have been put into the cover. As shown in Table 2, the circulation of business magazines has been very low in recent years.

Table 2. Business Magazines in Turkey and Their Circulations

\begin{tabular}{|c|c|c|c|}
\hline \multirow{2}{*}{ Business Magazine } & $\mathbf{2 0 1 0}$ & $\mathbf{2 0 1 1}$ & $\mathbf{2 0 1 2}$ \\
\cline { 2 - 4 } & $\begin{array}{c}\text { Average Net Sales } \\
\text { Per Issue }\end{array}$ & $\begin{array}{c}\text { Average Net Sales } \\
\text { Per Issue }\end{array}$ & $\begin{array}{c}\text { Average Net Sales } \\
\text { Per Issue }\end{array}$ \\
\hline Turkish Time & 1.873 & 1.117 & 1.283 \\
\hline Para & 10.527 & 11.215 & 8.953 \\
\hline Forbes & 10.016 & 17.684 & 14.665 \\
\hline Platin & 2.772 & 2.950 & 2.807 \\
\hline Infomag & 2.441 & 1.768 & 1.314 \\
\hline Capital & 9.455 & 9.657 & 8.613 \\
\hline Fortune $^{2}$ & 10.300 & 9.703 & 8.011 \\
\hline Ekovitrin $^{2}$ & 667 & 595 & 749 \\
\hline
\end{tabular}

Source: DPP, TDP

\footnotetext{
1 This section is summarized from "Economy Press History (in Turkish)" published by Turkish Journalists Association.

2 Cannot be reached net sales of some months.
} 


\section{Literature Review}

The question of whether recommendations published in newspapers or magazines would gain abnormal returns to investors examined extensively in the literature. The studies which investigated the recommendations in the Wall Street Journal (WSJ) Heard on the Street column; Davies and Canes (1978) indicated that buy recommendations provided significant positive abnormal returns on the day of publication for the period 1970-1971. Syed et al. (1989) observed positive abnormal returns on the publication day for the period 1983-1984. Liu et al. (1990) found that the HOTS column had an impact on the stock prices as well as the abnormal returns were associated with higher trading volumes. Pound and Zeckhauser (1990) focused to the takeover rumors, obtained no abnormal returns on the publication day. Beneish (1991) reported a significant positive abnormal return on publication date in the HOTS column for the period 1978-1979. Liu et al. (1992) investigated whether recommendations provide abnormal returns to investors for the period 1982-1985. Findings showed that investors could gain positive abnormal returns from the recommendations.

The studies investigated the recommendations which are published in the Wall Street Journal Dartboard column; Barber and Loeffer (1993) examined the effects cover the period 1988-1990. They detected positive abnormal returns on the publication day. Wright (1994), revealed a positive abnormal return on the publication day for the period 1988-1990. Allen and Awang-Damit (1998) indicated investor could gain positive abnormal returns before and on the publication date. However, the returns disappeared within a few days for the period 1990-1991. Albert and Smaby (1996) cover the period 1988-1991, found that positive abnormal returns could be earned on the publication day. Greene and Smart (1999) observed positive abnormal returns for the period 1988-1992. These returns gained in the first minutes of trading. Liang (1999) cover the period 1990-1994 showed that the abnormal returns were earned a few days before the publication. Pruitt et al. (2000) investigated the effects of recommendations on the stock returns for the period of 1994-1995. He found that positive abnormal returns could be gained on the publication day. Pettengill and Clark (2001) indicated that investor could earn positive abnormal returns cover the period 1990-1999.
The studies investigated the recommendations which are published in the Business Week "Inside Wall Street" column; Palmon et al. (1994) examined the effects of recommendations on the stock returns for the period 1983-1989. Findings indicated that positive abnormal returns could be earned on the publication day. Mathur and Waheed (1995) detected that abnormal returns were earned from two days before to the publication day for the period 1981-1989. Sant and Zaman (1996) showed that investors could earn positive abnormal returns around the publication day cover the period 1976-1998

In the other studies; Lee (1986) showed that investors were not able to earn abnormal returns from Heinz Biel column of Forbes for the period 1962-1979. Pieper et al. (1993) studied buy recommendations published in "Effekten-Spiegelin for the period 19901991. Findings showed that abnormal returns could gain before the publication of the recommendation. Benesh and Clark (1994) examined the effects of stock recommendation in Barron's. They found statistically significant market reaction on the publication date for the period 1987-1988. Desai and Jain (1995) indicated that investors could gain abnormal returns from stock recommendations in "Roundtable" by Barron's on the publication date cover the period 1968-1991. Ferreira and Smith (1999) did not find any significant abnormal returns for recommended stocks in the column of "Small Stock Focus" for 1993. Schmid and Zimmerman (2003) investigated the price and volume behavior around buy, sell and hold recommendations of Swiss stocks, published in Finanz und Wirtschaf newspaper in Switzerland for period 1998-2000. Findings showed that there was a significant price reaction on the publication date. Menendez (2005) analyzed the return and the trading volume of the analysts' recommendations, in Cinco Dias for the period 1997-1999. The findings indicated that market reacts before the publication of the recommendations. Liden (2006) examined effects of recommendations published in six Swedish newspapers and business magazines cover the period of 1996-2000. He found that buy recommendations were misleading the investors. Kerl and Walter (2007) analyzed buy recommendations published in German Personal Finance Magazines for the period 1995-2003. Findings indicated that recommendations provided abnormal returns within the five days around the publication day. Palmon et al. (2009) examined the effects of 
stock recommendations in Business Week, Forbes, and Fortune cover the period 2000-2003. They found investors could not earn abnormal returns in the long term. Lin et al. (2009), investigated whether investors could gain abnormal returns from the Economic Daily News in 2006. They found investors could gain abnormal returns on the publication date. Cervellati et al. (2014) searched the market reaction to recommendations on Italian financial newspaper Plus for the period 2005-2009. On the event day, they found significant positive abnormal returns.

In Turkey; Yazıcı and Muradoglu (2002) studied the impact of recommendations in Investor Ali column

Table 3. Summary of the Literature

\begin{tabular}{|c|c|c|c|}
\hline Author(s) & Publications & Periods & $\begin{array}{c}\text { Abnormal } \\
\text { Return }\end{array}$ \\
\hline Davies and Canes (1978) & WSJ-Heard on the Street & $1970-1971$ & Yes \\
\hline Lee (1986) & Forbes-Heinz Biel & $1962-1979$ & No \\
\hline Syed et al. (1989) & WSJ -Heard on the Street & $1983-1984$ & Yes \\
\hline Pound and Zeckhauser (1990) & WSJ -Heard on the Street & $1983-1985$ & No \\
\hline Liu et al. (1990) & WSJ -Heard on the Street & $1982-1985$ & Yes \\
\hline Beneish (1991) & WSJ -Heard on the Street & $1978-1979$ & Yes \\
\hline Liu et al. (1992) & WSJ -Heard on the Street & $1982-1985$ & Yes \\
\hline Barber and Loeffer (1993) & WSJ -Dartboard & $1988-1990$ & Yes \\
\hline Pieper et al. (1993) & Effekten-Spiegel & $1990-1991$ & Yes \\
\hline Wright (1994) & WSJ -Dartboard & $1988-1990$ & Yes \\
\hline Benesh and Clark (1994) & Barron's Mutual Choice & $1987-1988$ & Yes \\
\hline Palmon et al. (1994) & Business Week-Inside Wall Street & 1983-1989 & Yes \\
\hline Mathur ve Waheed (1995) & Business Week-Inside Wall Street & 1981-1989 & Yes \\
\hline Desai and Jain (1995) & Barron's-Roundtable & $1968-1991$ & Yes \\
\hline Albert and Smaby (1996) & WSJ -Dartboard & $1988-1991$ & Yes \\
\hline Sant and Zaman (1996) & Business Week-Inside Wall Street & 1976-1988 & Yes \\
\hline Allen and Awang-Damit (1998) & WSJ -Dartboard & $1990-1991$ & Yes \\
\hline Ferreira and Smith (1999) & Wall Street Journal-Small Stock Focus & 1993 & No \\
\hline Greene and Smart (1999) & WSJ -Dartboard & 1988-1992 & Yes \\
\hline Liang (1999) & WSJ -Dartboard & $1990-1994$ & Yes \\
\hline Pruitt et al. (2000) & WSJ -Dartboard & $1994-1995$ & Yes \\
\hline Kiymaz (2001) & Ekonomik Trend & 1996-1997 & $\mathrm{Yes}^{4}$ \\
\hline Pettengill and Clark (2001) & WSJ -Dartboard & 1990-1999 & Yes \\
\hline Yazıc1 and Muradoglu (2002) & Moneymatik-Investor Ali & 1993-1998 & $\mathrm{No}^{5}$ \\
\hline Schmid and Zimmerman (2003) & Finanz und Wirtschaft & $1998-2000$ & Yes \\
\hline Menendez (2005) & Cinco Dias & $1997-1999$ & Yes \\
\hline Liden (2006) & AFV; AB; FTi; GP; PA; VA ${ }^{6}$ & $1996-2000$ & Yes \\
\hline Kerl and Walter (2007) & Personal Finance Magazines & $1995-2003$ & Yes \\
\hline Palmon et al. (2009) & Business Week, Forbes and Fortune & $2000-2003$ & $\overline{\mathrm{No}}$ \\
\hline Lin et al. (2009) & Economic Daily News & 2006 & Yes \\
\hline Cervellati et al. (2014) & Plus & $2005-2009$ & Yes \\
\hline
\end{tabular}

\footnotetext{
4 Negative abnormal return.

5 In terms of small investors.

6 Affärsvärlden (AFV); Aftonbladet (AB); Finanstidningen (FTi); Göteborgsposten (GP); Privata Affärer (PA); and Veckans Affärer (VA)

7 In the long term.
} 
which is published in weekly economics journal of Moneymatik for the period 1993-1998. They obtained that recommendations did not help small investors to gain abnormal returns. Kiymaz (2001) searched the effects of stock market rumors in the HOTS column of "Economic Trend" on the prices of stocks for the period 1996-1997. The findings showed that the positive significant abnormal returns were observed before the publication date; the negative insignificant abnormal returns were detected in the postpublication period.

This paper contributes to the existing literature in various ways. The studies related to the emerging or developing countries are far and few. Moreover there has been an impressive growth in Turkish market recently. Additionally in the study of Kiymaz (2001) period was too short and he was taken into consideration only the recommendations for the manufacturing industry. Also in the study of Yazıcı and Muradoglu (2002) only one stock was considered among the recommended stocks. In the current study, the period is determined in approximately seven years and taking into account all recommended stocks in the magazine. The studies reported in the literature are summarized in Table 3.

\section{Data and Methodology}

The aim of the study is to examine whether investors can earn abnormal returns from stocks, which are given buy recommendations from weekly business magazine Para, cover the period February 2006-December 2012. The event study is used to analyze the effects of recommendations on the stock prices as suggested by Brown and Warner (1985). The event study allows researchers to measure the impacts of an event (for example stock recommendation) on the firm value and test market efficiency (Palmon et al. 2009 , p. 213). The analysis periods extend from day $\mathrm{t}-1$ to $\mathrm{t}+5, \mathrm{t}+1$ to $\mathrm{t}+5, \mathrm{t}-5$ to $\mathrm{t}+5$ and $\mathrm{t}+1$ to $\mathrm{t}+260$ relative to publication date $\mathrm{t}=0$.

In Turkey, weekly magazine Para is the only magazine that gives stock recommendation regularly. That is why it has been selected. It began to broadcast life in October 2004 and it is one the most important publication on the financial markets in recent years. It is published on Sundays, in the magazine Business and company news, macroeconomic outlook of Turkey, news from the global financial markets, and news in the Turkish money market, technical analysis of BIST and stock recommendations exist on a regular basis. Also the stock recommendation section appears regularly in large letters on the cover page of each issue. The content of the stock recommendation section consists of an explanation of analysis made by analysts in different brokerage houses. Analysts use fundamental analysis for to determine the favorite stocks. Our sample consists of 1574 stock recommendations for 244 different stocks. Additionally, in 5 issues of Para are not given any recommendation. Recommended prices of the stocks are obtained from isyatırım.com.tr.

\section{Empirical Results}

The empirical results are reported in Tables 4 to 6 and Figures 3 to 5 . The daily average abnormal returns (AARs) for all buy recommendations are computed for analysis period to relative to the event day.

Table 4. AARs and ACARs in $t+1, t+5$ Period

\begin{tabular}{c|c|c|c|c}
\hline Business Days & AARs (\%) & t value & $\begin{array}{c}\text { ACARs (\%) } \\
(+\mathbf{1},+\mathbf{5})\end{array}$ & t value (+1,+5) \\
\hline $\mathrm{t}+1$ & 0.10 & 1,344 & 0.16 & $5,545^{*}$ \\
\hline $\mathrm{t}+2$ & -0.04 & $-0,604$ & & \\
\hline $\mathrm{t}+3$ & 0.14 & $1,905^{* * *}$ & & \\
\hline $\mathrm{t}+4$ & -0.06 & $-0,737$ & & \\
\hline $\mathrm{t}+5$ & 0.02 & 0,362 & & \\
\hline${ }^{*} \mathrm{p}<0,01 ; * \mathrm{p}<0,05 ; * * \mathrm{p}<0,10$ &
\end{tabular}


Table 4 display the AARs and average cumulative abnormal returns (ACARs) for the event period $t+1$, $t+5$. Findings show that Para has not a significant impact on stock prices. There is no significant reaction on the first trading day (Monday) after the recommendation but there is only a significant abnormal return on the $t+3$ day. AARs are $0.1 \%$ on day $t+1$, $-0.04 \%$ on day $t+2,0.14 \%$ on day $t+3,-0.06 \%$ on day $t+4$, and $-0.02 \%$ on day $t+5$. Moreover ACARs for the period $(t+1, t+5)$ is statistically significant at the $1 \%$ level but the ACARs is only $0.16 \%$.

As a further analysis, we investigate the behavior of stock prices for one-week before and after $(t-5, t+5)$ the publication of the Para. Table 5 and Figure 2 report the results of the ten day event period.

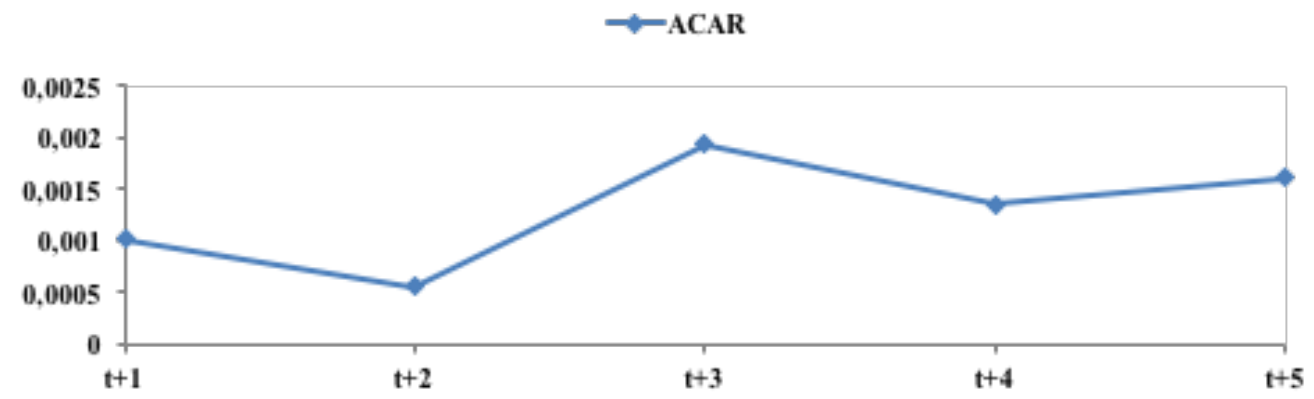

Figure 3. ACARs in $t+1, t+5$ Period

Table 5. AARs and ACARs in $t-5, t+5$ Period

\begin{tabular}{|c|c|c|c|c|}
\hline Business Days & AARs (\%) & t value & $\begin{array}{c}\text { ACARs (\%) } \\
(-\mathbf{5},+\mathbf{5})\end{array}$ & t value (-5,+5) \\
\hline $\mathrm{t}-5$ & 0,10 & 1,461 & 0,66 & $7,783^{*}$ \\
\hline $\mathrm{t}-4$ & 0,11 & $1,734^{* * *}$ & & \\
\hline $\mathrm{t}-3$ & 0,16 & 0,924 & & \\
\hline $\mathrm{t}-2$ & 0,06 & 1,039 & & \\
\hline $\mathrm{t}-1$ & 0,04 & 0,571 & & \\
\hline $\mathrm{t}+1$ & 0,10 & 1,344 & & \\
\hline $\mathrm{t}+2$ & $-0,04$ & $-0,604$ & & \\
\hline $\mathrm{t}+3$ & 0,14 & $1,905^{* * *}$ & & \\
\hline $\mathrm{t}+4$ & $-0,05$ & $-0,737$ & & \\
\hline $\mathrm{t}+5$ & 0,02 & 0,362 & & \\
\hline
\end{tabular}

${ }^{*} \mathrm{p}<0,01 ;{ }^{* *} \mathrm{p}<0,05 ;{ }^{* * *} \mathrm{p}<0,10$.

Table 5 shows that ACARs are in ten day event period are positive for each business day. AAR is also positive for all days except $t+2$ and $t+4$ days. Moreover AARs in the $t-4$ and the $t+3$ event days are statistically significant at the level of $10 \%$. But it is hard to say that existence of statistically significant and positive abnormal return on the $t-4$ day as insider trading. The ACARs, illustrated in Figure 2, begin to increase in $\mathrm{t}-5$ day prior to publication day and rises on $\mathrm{t}+3$ day.
The ACARs for ten days period is $0.66 \%$ which is statistically significant at the level of $1 \%$.

Despite the poor performance of the stocks in the short run, recommendation might be profitable in the long run. Table 6 and Figure 3 indicate the performances of recommended stocks in the one year $(t+1$, $t+260$ ) period. 


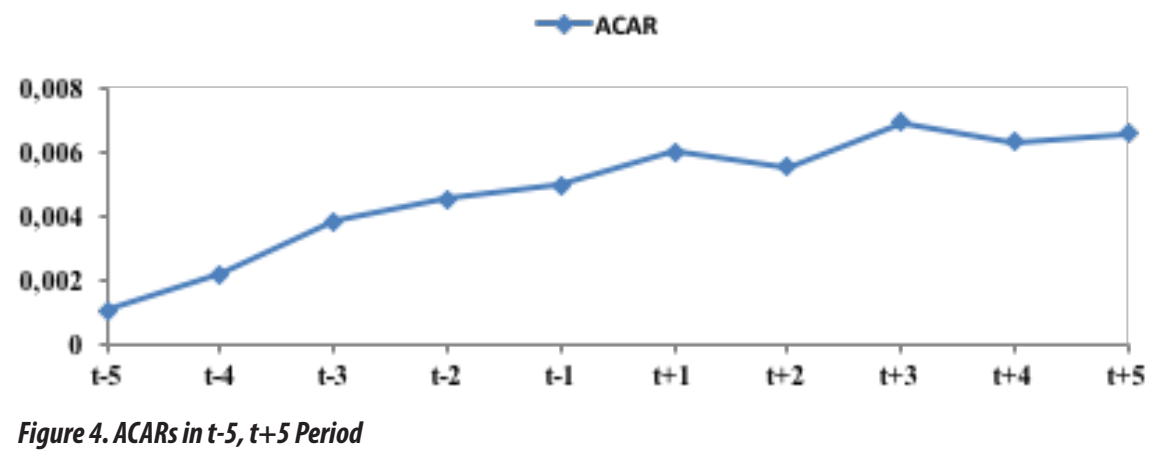

\section{Table 6. AARs and ACARs in $t+1, t+260$ Period}

\begin{tabular}{c|c|c|c|c}
\hline Business Days & AARs (\%) & t value & $\begin{array}{c}\text { ACARs (\%) } \\
(+\mathbf{1},+\mathbf{2 6 0})\end{array}$ & $\begin{array}{c}\text { t value } \\
(+\mathbf{+ 1}+\mathbf{+ 2 6 0})^{*}\end{array}$ \\
\hline $\mathrm{t}+1$ & 0,10 & 1,344 & 1,2 & 13,194 \\
\hline $\mathrm{t}+20$ & 0,06 & 0,786 & & \\
\hline $\mathrm{t}+40$ & 0,07 & 1,173 & & \\
\hline $\mathrm{t}+60$ & 0,06 & 0,855 & & \\
\hline $\mathrm{t}+80$ & 0,12 & $1,802 * * *$ & & \\
\hline $\mathrm{t}+100$ & $-0,1$ & $-1,594$ & & \\
\hline $\mathrm{t}+120$ & 0,05 & 0,786 & & \\
\hline $\mathrm{t}+140$ & $-0,13$ & $-1,588$ & & \\
\hline $\mathrm{t}+160$ & 0,15 & $2,244 * *$ & & \\
\hline $\mathrm{t}+180$ & 0,03 & 0,398 & & \\
\hline $\mathrm{t}+200$ & $-0,1$ & $-1,582$ & & \\
\hline $\mathrm{t}+220$ & 0,01 & 0,184 & & \\
\hline $\mathrm{t}+240$ & $-0,02$ & $-0,387$ & & \\
\hline $\mathrm{t}+260$ & $-0,05$ & $-0,698$ & & \\
\hline
\end{tabular}

${ }^{\star} \mathrm{p}<0,01 ;{ }^{* *} \mathrm{p}<0,05 ;{ }^{* * *} \mathrm{p}<0,10$.

Figure 3 shows the recommended stocks one year performances. ACARs are almost above zero in $t+1$, $t+101$ period. But ACARs are negative between the periods of $t+1, t+101 ; t+150, t+160$ and $t+181, t+202$. The recommended stocks performance turns to positive 202 days after the publication. The stocks per- formances are $1.2 \%$ better than the BIST- 100 performance in the one year period. As a result, recommendations do not help to investors to earn abnormal returns in the long-run. Moreover statistically significant abnormal returns show that BIST is not efficient within the semi-strong form. 


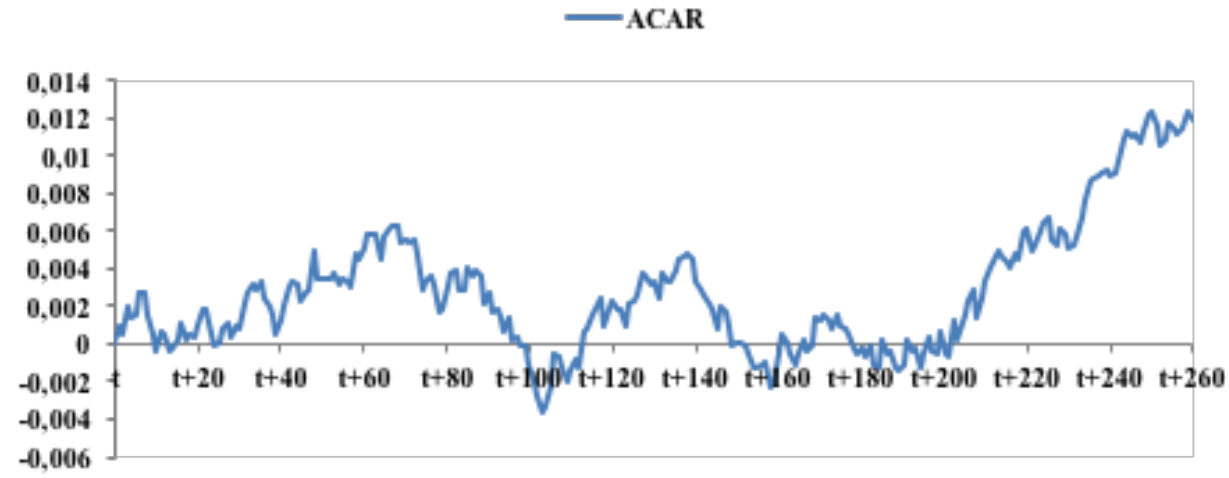

Figure 5. ACARs in $t+1, t+260$ Period

\section{Conclusion}

Business magazines are an important source, especially for small investors searching for information or recommendation about stocks. This study investigates whether stock recommendations given by business magazines can help investors to earn abnormal returns. Sample consists of stocks which are recommended as a "buy" by weekly business magazine Para. For the period of February 2006-December 2012 recommendations have been used in the study and day of the publishing of magazine has been chosen as the $(t=0)$ event day. Business days the before $t$ day as a $\mathrm{t}-1, \mathrm{t}-2$ and business days of the after $\mathrm{t}$ day as a $\mathrm{t}+1$, $t+2$ have been numbered. Average abnormal returns (AAR) and average cumulative abnormal returns (ACAR) of stocks have been computed for each business day.

Results show that the first day $(\mathrm{t}+1)$ after publication of recommendation, ARR calculated as $0.10 \%$, but it is not statistically significant. So, it indicates that Para has not a significant impact on stock prices. Also ACARs is shown to be $0.16 \%$ for the period of five business days $(\mathrm{t}+1, \ldots, \mathrm{t}+5)$.

For the ten day period $(t-5, t+5) t-4$ day is found the only significant day within pre-event days. Hence the observed market reaction can hardly be explained by insider trading. Also, in this period, ACAR has been increased consistently and calculated as $0.60 \%$ from $\mathrm{t}-5$ to $\mathrm{t}+1$.
Despite the poor performance of the recommended stocks in the short run, the stocks are also analyzed for the long run. As time progressed in analysis period, it is found that recommendations performance is the same as the BIST-100 index performance. So recommendations are not earned abnormal returns to investors. ACAR has been calculated negatively for each business day from $t+8$ day. ACAR has been calculated $0.33 \%$ hypothetically holds in reserve during 6 months of recommended stocks. For one year period $(t+1, \ldots, t+260)$, recommended stocks are gained only \%1.2 abnormal returns to its investors. In conclusion, if investors making an investment decision regarding these recommendations, it will not provide much advantage for them. Business magazines are important source, especially for small investors but they have a low circulation in Turkey so they have a limited effect on stocks. Institutional investors have the largest power on the BIST and they mostly consider the reports of the financial experts like brokerage houses.

These findings are consistent with many studies in the literature which are revealed that recommendations cannot help to investors to earn abnormal returns from stocks (Lee, 1986; Pound and Zeckhauser, 1990; Ferreira and Smith, 1999; Yazıc1 and Muradoglu, 2002; Lin et al., 2009). In addition, calculated ACARs for all periods $(+1,+5 ;-5,+5 ;+1,+260)$ in the study are significant at the level of $\% 1$. In terms of testing the market efficiency, the existence of positive and significant ACARs, show that BIST is not efficient in semi strong form. 


\section{Limitations}

Although the study provides important insights about the effects of business recommendations on the stock returns, the study has some limitations. The first limitation is sample period. Period covers the February 2006-December 2012. The second limitation is the sample size. It is restricted to one magazine because there is no any business magazine that gives stock recommendation regularly in Turkey. Lastly, it is possible that the study may not fully reflect effects of business magazines compared to the other studies because of the low circulation of business magazines in Turkey. In the further studies the sample period might be expanded or the effects of newspaper can be examined.

\section{References}

Albert, Jr. R. and Smaby, T. (1996). Market Response to Analyst Recommendations in the 'Dartboard' Column: The Information and Price-Pressure Effects, Review of Financial Economics, 5, 59-74.

Allen, David S., Awang-Damit, H. (1998). The Wall Street Journal Investment Dartboard, Flagstaff: Northern Arizona University, College of Business Administration, Working Paper.

Barber, B. M., Loeffler, D. (1993). The Dartboard Column: Second-Hand Information and Price Pressure, Journal of Financial and Quantitative Analysis, 28, 273-284.

Beneish, M.D. (1991). Stock Prices and the Dissemination of Analysts' Recommendations, Journal of Business, 64, 393-416.

Benesh, G., Clark, J. (1994). The Value of Indirect Investment Advice: Stock Recommendations in Barron's, Journal of Financial and Strategic Decisions, 7(1), 35-43.

BIST, http://borsaistanbul.com/veriler/verileralt/hisse-senetleri-piyasasi-verileri, 10.06.2013.

Brooks, R. M., Ajay P., Tie S. (2003). How the Equity Market Responds to Unanticipated Events, Journal of Business, 76, 109-133.
Brown, S.J., Warner J.B., (1985). Using Daily Stock Returns: The Case of Event Studies, Journal of Financial Economics, 14, 3-31.

Business Magazine of PARA. 26 February 2006-26 December 2010.

Cervellati E. M., Ferretti R., Pattitoni, P. (2014). Market Reaction to Second-Hand News: Inside the Attention-Grabbing Hypothesis, Applied Economics, 46(10), 1108-1121

Davies, P. L., Canes, M. (1978). Stock Prices and the Publication of Second-Hand Information, Journal of Business, 51, 43-56.

Dergi Pazarlama ve Planlama (DPP). http://www.dpp. com.tr/.

Desai, H., Jain P. C. (1995). An Analysis of the Recommendations of the 'Superstar' Money Managers at Barron's Annual Roundtable, The Journal of Finance, 50(4), 1257-1273.

Fama E. F. (1970). Efficient Capital Markets: A View Theory and Empirical Work, The Journal of Finance, 25(2), 383-416.

Ferreira, E. J., Smith, S.D. (1999). Stock Price Reactions to Recommendations in the Wall Street Journal 'Small Stock Focus' Column, The Quarterly Review of Economics and Finance, 39, 379-389.

Graham, J. R. Koski, J. F., Loewenstein, U. (2006). Information Own and Liquidity around Anticipated and Unanticipated Dividend Announcements, Journal of Business, 79, 2301-2336.

Greene, J., Smart, S. (1999). Liquidity Provision and Noise Trading Evidence from the 'Investment Dartboard' Column, The Journal of Finance, 54(5), 1885-1899.

BİST, http://borsaistanbul.com/en/corporate/aboutborsa-istanbul/about-us, 12.06.2013.

Isyatırım, http://www.isyatirim.com.tr/ 10.06.2013. 
Kalay, A., Kronlund, M. (2014). The Market Reaction to Stock Split Announcements: Earnings Information After All, https://-www0.gsb.columbia.edu/mygsb/-faculty/-research/pubfiles/-5520/stocksplits.pdf, 12.10.2014.

Kerl, A., Walter A. (2007). Market Responses to Buy Recommendations Issued by Personal Finance Magazines: Effects of Information, Price-Pressure, and Company Characteristics, Review of Finance, $11,117-141$

Kiymaz, H. (2001). The Effects of Stock Market Rumors on Stock Prices: Evidence from an Emerging Market, Journal of Multinational Financial Management, 11, 105-115.

Lee, J. C. (1986). Information Content of Financial Columns, Journal of Economics and Business, 38, 27-39.

Liden, E. R. (2006). Stock Recommendations in Swedish Printed Media: Leading or Misleading?, The European Journal of Finance, 12(8), 731-748.

Liang, B. (1999). Price Pressure Evidence from the 'Dartboard' Column, The Journal of Business, 72(1), 119-134.

Lin, C., F. Lin, Wang, Y. (2009). Can Investors Profit from the Stock Recommendations on the Journalism? Testing Conditional Heteroscedasticity in the Market Model, International Research Journal of Finance and Economics, ISSN 1450-2887, 33,111118.

Liu, P., Smith, D., Syed, A. (1990). Stock reaction to the Wall Street Journal's Securities Recommendations, Journal of Financial and Quantitative Analysis, 25, 399-410.

Liu, P., Smith, S. D., Syed, A. (1992). The Impact of Insider Trading Scandal on the Information Content of the Wall Street Journal's 'Heard On The Street' Column, Journal of Financial Research, 15, 181188.
Mathur, I., Waheed, A. (1995). Stock Price Reactions to Securities Recommended in Business Week's 'Inside Wall Street, In the Financial Review, 30(3), 583-604.

Menendez, S. (2005). Market Valuation of the Analysts' Recommendations the Spanish Stock Market, Applied Financial Economics, 15, 509-518.

Palmon, O., Sun, H.L., Tang, A. P. (1994). The Impact of Publication of Analysts' Recommendations on Returns and Trading Volumes, The Financial Review, 29, 395-417

Palmon D., Sudit F., Yezegel, A. (2009). The Value of Columnists' Stock Recommendations, Review of Quantitative Finance and Accounting, 33(3), 209232.

Pettengill, G. N., Clark, J. M. (2001). Estimating Expected Returns in an Event Study Framework: Evidence from The Dartboard Column, Quarterly Journal of Business and Economics, 40, 3-21.

Pieper, U., Schiereck, D., Weber, M. (1993). Die Kaufempfehlungen des "Effecten-Spiegel"-Eine empirische Untersuchung im Lichte der Effizienzthese des Kapitalmarktes", Zeitschrift für betriebswirtschaftliche Forschung, 45, 487-509.

Pound, J., Zeckhauser, R. J. (1990). Clearly Heard on the Street. The Effect of Takeover Rumors on Stock Prices. Journal of Business, 63(3), 291-308.

Pruitt, S. W., Van Ness, B. F., Van Ness, R. A. (2000). Clientele Trading in Response to Published Information: Evidence From The Dartboard Column, The Journal of Financial Research, 23, 1-12.

Sant, R., Zaman, M. A. (1996). Market Reaction to Business Week 'Inside Wall Street' Column: A SelfFulfilling Prophecy, Journal of Banking \& Finance, 20, 617-643. 
Schmid, M., Zimmerman, H. (2003). Performance of Second Hand Public Investment Recommendations, National Centre of Competence in Research Financial Valuation and Risk Management, Working Paper No. 101.

Schuster, T. (2003). Fifty-Fifty Stock Recommendations and Stock Prices Effects and Benefits of Investment Advice in the Business Media, Leipzig University Working Paper, No. 03-01, http://www. tomschuster.de/EmpfehlungUS.pdf.

Syed, A. A., Liu, P., Smith, S. D. (1989). The Exploitation of Inside Information at the Wall Street Journal - A Test Of Strong Form Efficiency, Financial Review, 24, 567-579.

Turkish Journalists Association. (2008). Economy Press History, Publisher: Turkish Journalists Association Publicians (in Turkish).

Turkuaz Dağıtım ve Pazarlama (TDP). http://www. tdp.com.tr/tr/home/
World Federation of Exchanges (WFE). http://www. world-exchanges.org/statistics. 01.03.2014.

Wright, D. W. (1994). Can Prices be Trusted? A Test of the Ability of Experts to Outperform or Influence the Market, Journal of Accounting, Auditing and Finance, 9, 307-323.

Wuff, C. (2002). The Market Reaction to Stock SplitsEvidence from Germany, Schmalenbach Business Review, 54, 270-297.

Yazıc1, B., Muradoglu, G. (2002). Dissemination of Stock Recommendations and Small Investors: Who Benefits?, Multinational Finance Journal, 6, 29-42.

Yoon, P. S., Starks, L. T. (1995). Signaling, Investment Opportunities, and Dividend Announcements, Review of Financial Studies, 8, 995-1018. 